\title{
Syndromics: A Bioinformatics Approach for Neurotrauma Research
}

\author{
Adam R. Ferguson • Ellen D. Stück • Jessica L. Nielson
}

Received: 1 August 2011 /Revised: 14 October 2011 / Accepted: 18 October 2011 / Published online: 18 November 2011

(C) The Author(s) 2011. This article is published with open access at Springerlink.com

\begin{abstract}
Substantial scientific progress has been made in the past 50 years in delineating many of the biological mechanisms involved in the primary and secondary injuries following trauma to the spinal cord and brain. These advances have highlighted numerous potential therapeutic approaches that may help restore function after injury. Despite these advances, bench-to-bedside translation has remained elusive. Translational testing of novel therapies requires standardized measures of function for comparison across different laboratories, paradigms, and species. Although numerous functional assessments have been developed in animal models, it remains unclear how to best integrate this information to describe the complete translational "syndrome" produced by neurotrauma. The present paper describes a multivariate statistical framework for integrating diverse neurotrauma data and reviews the few papers to date that have taken an information-intensive approach for basic neurotrauma research. We argue that these papers can be described as the seminal works of a new field that we call "syndromics", which aim to apply informatics tools to disease models to characterize the full set of mechanistic inter-relationships from multi-scale data. In the future, centralized databases of raw neurotrauma data will enable better syndromic approaches and aid future translational research, leading to more efficient testing regimens and more clinically relevant findings.
\end{abstract}

Keywords Spinal cord injury - Traumatic brain injury . Multivariate statistics · Outcome measures · Assessment

\footnotetext{
A. R. Ferguson $(\bowtie) \cdot$ E. D. Stück $\cdot$ J. L. Nielson

Brain and Spinal Injury Center (BASIC),

Department of Neurological Surgery, University of California,

1001 Potrero Avenue, Building 1, Room 101,

San Francisco, CA 94110, USA

e-mail: adam.ferguson@ucsf.edu
}

\section{Introduction}

Basic research on spinal cord injury (SCI) and traumatic brain injury (TBI) has sought to tackle the complex biological milieu produced by trauma and reduce it down to its fundamental mechanistic processes for therapeutic targeting. Over the past 50 years, this approach has uncovered numerous biological mechanisms contributing to dysfunction, including oxidative-stress $(1-3)$, apoptotic cell death $(4,5)$, tissue loss $(6,7)$, neuroinflammation (8-11), alterations in organization and plasticity (12-16), and long-term changes in function (17-25), among others. This intensive effort has provided a wealth of knowledge about individual patho-biological mechanisms; however, translation of this knowledge into human therapeutics has remained elusive (26-30). Largescale integration of diverse mechanistic findings has the potential to aid in translation by characterizing the complex constellation (i.e., the "syndrome") of biological and functional changes after trauma. Syndrome-detection from diverse sources of raw data requires the application of computationally intensive integrative approaches that are, at the present time, uncommon in the basic neurotrauma literature. The current paper reviews the diverse biological and functional measures that have been characterized for both SCI and TBI, providing a data-rich framework from which syndrome-level analyses can be built. We then review the few recent studies that have used systems biology approaches to integrate diverse neurotrauma data. We argue that these papers can be viewed as the seminal works of a new field that we call "syndromics" which aims to understand complex disease states as integrated and wellcharacterized syndromes that can be quantified through the use of bioinformatics approaches (Fig. 1). This approach borrows from methods currently used in epidemiology known as "syndromic surveillance" to monitor and predict 
GOALS OF SYNDROMIC PROCESSING

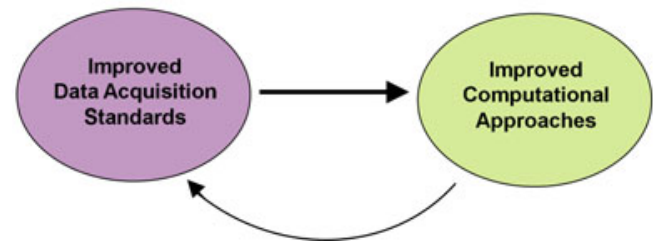

Fig. 1 Iterative relationship between data acquisition and computational results

disease outbreaks by integrating diverse sources of information (31). We use the term syndromics to refer to a similar paradigm applied to preclinical, mechanistic studies with the goal of providing a translational bridge between the clinical and preclinical literature. The term syndromics is also reminiscent of other computational biology frameworks such as "genomics" and "proteomics", involving the integration of diverse genetic and protein expression information, respectively. The statistical methods used in syndromics are very similar to these other "omics"; however the data analyzed tend to be more multi-scalar in nature.

A fundamental premise of syndromics is that it is possible to integrate diverse measures from multiple biological and functional assays into a unified snapshot of the state of the affected individual. In the following review, we first discuss some of the pathological and functional consequences observed following neurotrauma, and the outcome measures used to assess them. We then review some of the statistical techniques that could be applied to neurotrauma data for syndromic integration of these multiple outcomes. Most of the preclinical examples come from SCI; however, syndromics is a general framework that can be applied to TBI, stroke, and other disease models as well.

\section{One Traumatic Event, Multiple Interrelated Biological Effects}

Traumatic injury to the central nervous system (CNS) produces complex biological sequelae. For example, SCI alters expression of a wide range of genomic and proteomic markers (32-37). These complex molecular events are involved in a cascade of biological changes, including cell damage through excitoxicity and lipid peroxidation, resulting in cell death through necrosis and apoptosis $(4,38-44)$. Each of these cell-death responses has a variety of telltale markers. For example, excitotoxicity is associated with cytoplasmic swelling $(45,46)$, increased calcium $\left(\mathrm{Ca}^{2+}\right)$ influx $(47,48)$, alterations in glutamate receptors $(41,49$, $50)$, changes in membrane permeability $(51,52)$, and acute electrophysiological changes (53-55). Apoptosis has been measured through distinctive morphological changes such as nuclear fragmentation and chromatin condensation (4, 56 ) or through a variety of cell signaling markers including positive labeling for TUNEL, caspases, fluorojade-B, and others $(4,57-62)$.

Cell death and compensatory repair occur in a dynamically changing tissue microenvironment that includes changes in inflammatory cytokine levels, altered inflammatory states in CNS microglia, and waves of CNS infiltration by circulating immune cells $(9,63-67)$. This neuroinflammation has been implicated in cell death and secondary injury $(41,68-74)$ as well as neuroprotection and repair (75-78). This speaks to the complexity of the interrelationships between different biological mechanisms and highlights the difficulty with predicting outcome using only one or two isolated biomarkers (79-82). The emergent relationships among multiple measures could help define the conditions under which a particular simple relationship prevails over another. For example, proinflammatory cytokines such as tumor necrosis factor alpha (TNF $\alpha)$ are released following trauma to the nervous system $(83,84)$ and can either have detrimental effects such as contributing to neural cell death $(41,85)$, or can serve a neuroprotective function (86-88), depending on the context. However, the specific factors dictating $\mathrm{TNF} \alpha$ function are not well understood, and different conclusions can be made by monitoring different aspects of TNF signaling. The failure to account for complex, multi-inflected interactions among outcomes reduces replicability of findings and leads to controversies that could be resolved by including a more complete set of measures, reflecting a more complete set of biological mechanisms.

Like cell-death measurements, histological sparing after neurotrauma is often quantified using multiple different measurements. For example in the SCI literature, common morphometric measurements include cross-sectional gray matter sparing, white matter sparing, and lesion area and volume $(6,89-93)$. In addition, it is common for researchers to use more specific immunohistochemical markers to measure specific cellular and subcellular changes $(4,5,66$, 67, 94, 95). For example, changes in oligodendrocyte precursor cell proliferation/differentiation have been measured as harbingers of white matter sparing and remyelination (96-102). Motor neuron sparing can be quantified as an assay of functional gray matter sparing (41). Reactive astrocytes have been measured with a specific focus on their relationship to the glial scar (103-105). Microglia/ monocyte numbers and activity state have been quantified to characterize their relationship to other morphological changes (106-109).

This litany of changes, ranging from subcellular to histological, is thought to have implications for not only cell death but also compensatory plasticity after neurotrauma. To measure morphological plasticity such as 
regeneration and sprouting, anterograde tracers have been used to target specific tracts of interest such as the corticospinal tract (CST) $(16,110-114)$, rubrospinal tract $(115,116)$, and motor unit organization $(117,118)$, among others. The relationship between these regenerative changes and other histological changes such as growth factor levels (119-121) and breakdown of the glial scar $(122,123)$ are thought to predict the degree of axonal regrowth across the lesion and provide a substrate for functional recovery (110, 122-124).

In addition to regeneration across the lesion, there is substantial plasticity and reorganization at sites remote to a focal neurotrauma. For example, in the SCI literature, it has been well established that there is plasticity and functional reorganization below a complete transection $(117,124$ 131). With training, the spinal cord is capable of learning a variety of motor tasks, including Pavlovian associations (132-136), instrumental learning $(129,131,137-141)$ and stepping on a treadmill $(124,125,142-146)$. This capacity for use-dependent plasticity in the spinal cord has been shown to rely upon propriospinal tract relays (124) and glutamate receptor-mediated plasticity in the lumbar cord $(147,148)$. There is also substantial reorganization in the cortex following SCI (149-157), which appears to be largely mediated by the extent of use of the relative areas represented in the cortex and compensation from the surrounding representations occurs to promote functional recovery.

Recovery after injury is likely to result from a complex amalgamation of all of these tissue changes working in concert to generate the functional state of the affected individual. Detecting systematic patterns from this complexity is a daunting task, however, advanced computational approaches have been effectively used to deal with similar levels of complexity in other fields, including information systems (158), physics $(159,160)$, meteorology (161), economics (162), epidemiology (163-165), psychology (166), chemometrics $(167,168)$, genomics (169-173), and proteomics (174). The general approach for these fields has been to build vast data repositories that allow integration of multiple pieces of information using multivariate statistics. By taking a similar approach to neurotrauma, syndromics provides an opportunity to leverage state-of-the art knowledge about multiple biological mechanisms to predict functional recovery (16) and compare findings across species $(175,176)$.

\section{One Traumatic Event, Multiple Functional Consequences}

Functional changes are a hallmark of neurotrauma and are the major target for treatment of affected patients (177). SCI is associated with a wide range of functional disturbances including pathological pain and other sensory changes, loss of sexual function, bladder and bowel changes, and motor impairments (for review see (178)). Biological mechanisms are important for therapeutic development, yet the ultimate goal is to affect function. Therefore, it is critical to understand precisely what we are measuring when we take functional measures after neurotrauma. Ultimately, this issue falls within the field of psychometrics, the scientific discipline concerned with neurobehavioral scale development and metric validation $(179,180)$. Psychometrics is a vast literature (181-183) that provides standards for assessing reliability and validity of a given scale. This field that has given rise to many of the tools used for clinical neurological assessment after neurotrauma, such as neuropsychological testing batteries (184-186), personality inventories (187), PTSD measures (188), quality-of-life indices (189-191), and functional independence measures (192-197). Many of the basic principles from this scientific discipline, such as guidelines for reliability and validity assessment, have been applied in the clinical neurotrauma literature (197-210). However, the basic research community in neurotrauma has been less attentive to the scale development concerns (for exceptions see (211-214)), and metric properties studies are largely lacking (215).

Despite the lack of clarity about reliability and validity testing for many of the current scales, over the last 50 years, the basic SCI literature has produced numerous measures to assess injury at a behavioral level $(16,25,157,211-214$, 216-236). A full summary of most of these methods is beyond the scope of the present paper and have been reviewed in detail elsewhere (237-244). Some of the most popular measures have been open-field locomotor assessments $(211,212,217,230,231)$, footprint analysis (218, 232-234, 245), and fine-grained physiological outcomes such as electromyography (EMG) and kinematics (222, 234-236, 246-249). Additional functional assessments have included the inclined plane test, and various methods for assessing contact placing responses and foot-placement such as gridwalk test, beam walk, and the horizontal ladder $(25,89,92,241,250-252)$.

There is little consensus about what is the most appropriate or "best" measure of outcome after experimental neurotrauma. It is therefore common for researchers to perform a battery of functional assessments in the context of therapeutic testing (241). Since there are no clear rules for determining which subsets of outcomes should be reported in published work, researchers often report only a subset of the collected data in a given publication to highlight statistically significant effects and to achieve clarity of presentation. This opens the possibility that researchers can repeatedly test their hypothesis on multiple outcomes and then make strong conclusions on a minority 
of outcomes that show significant effects. Such an approach increases the risk of a type I error (reporting a significant effect when there is not one). This is perhaps highlighted by the recent high-profile studies in which researchers have been unable to replicate each other's work in the preclinical setting (253-257). On the other hand, it is possible that different functional measures reflect different components of the complex, multifaceted syndrome that follows SCI. It is possible, for example, that animals could perform well on a test of open field locomotion, but still lack some of the modulatory sensory or reflex function that is necessary for locomotion in a complex environment with obstacles and variations in surface texture (258). Conversely, rearrangement of the somatosensory cortex following SCI suggests that an animal could perform well on tests of sensory function but lack the lower motor neuron control necessary for open-field locomotion (150). Thus, there is a need for comprehensive scales that capture all of the subcomponents involved in normal function, producing global, syndrome scores that reflect the entire functional state of the animal.

In an attempt to address this issue, some researchers have used integrative scales or testing batteries that combine elements of several of the scales discussed in previous sections $(216,241,259)$. For example, in the follow-up paper to the 1954 publication of his influential locomotor scale, Tarlov reported that there were different time courses for recovery of tactile nociception (pin-prick) and locomotion, providing a window into the complex interactions between sensory and motor function (217, 259). In keeping with this tradition, Gale et al. (1985) incorporated sensory function as well as multiple motor indices in their complex test, the combined behavioral score (CBS). The CBS consists of eight subtests that were designed to tap into locomotion, proprioception, cutaneous reflexes, posture, and nociceptive processing. The raw scores from these subtests are converted to reverseweighted CBS subscores and then added to yield a scale that ranges from 0 (no dysfunction) to 100 (complete dysfunction). Therefore, the global CBS can be interpreted as a percent dysfunction (216).

Following the initial development of the CBS, several papers came out suggesting that it was highly correlated with less extensive outcomes such as the five-point Tarlov open-field scores and the inclined plane test (260-263). Some reports suggested that exclusion of some of the subtests on the CBS reduces extraneous variability, resulting in greater validity with regard to lesion size (264). In 1995, a modified version of the Tarlov scale was produced by Basso, Beattie, and Bresnahan (BBB) (211) that was subjected to careful reliability (265) and validity testing $(211,265)$ as part of the multicenter animal SCI study (MASCIS) (266). The BBB was released with welldesigned, easy-to-use scoring sheets and training materials.
Subsequent work revealed that multiple other measurement techniques did not provide substantial gains in useful information over the BBB (241), and the field adopted this easy-to-use locomotor outcome as the de facto standard for functional assessment in rodent SCI models, garnering over 1,100 citations since its release in 1995 (267). Subsequent modifications have been made to this scale, including one specifically for use in mouse models (212), one utilizing a straight ally testing field (230), and one that uses a computer program to assist with recording and scoring (268).

It has been pointed out that there is often an inverse relationship between ease-of-use of a scale and its precision (237). On one end of the spectrum, there are simple-to-use, but error-prone scales like the five-point Tarlov (217), which describes function using ambiguous terms such as "good movement of the joints" (score = 2) and "complete recovery" (score $=4$ ). On the other end of the spectrum are high-resolution kinematic measures using high-speed, highdefinition cameras, and precision placement of joint markers with SMPTE timestamps for data alignment with electrophysiological outputs $(224,247,269-272)$. The former may lack the precision necessary to detect incremental functional improvement whereas the latter produces high-precision, but at a cost in money, analysis time, and expertise required (237). The BBB scale attempts to strike a balance between these two extremes by providing strict operational definitions intended to guide observational scoring and increase reliability (265). However, the BBB has been criticized for its insensitivity in the extreme lower and upper portions of the scale where incremental improvements in function may not be accurately represented as incremental improvement in score $(215,273)$. For example, inter-limb coordination as measured by the upper end of the BBB scale shows some statistical wobble (215) and does not always correlate with results from detailed analysis of stepping patterns using automated footprint analysis (245, 273), kinematics (274), or robotic gait analysis (275). A fundamental issue that arises from these comparisons is: "What are the best measures of function?" The answer to this question is not always clear, and in many cases, it can be countered with another question: "Better for what purpose?", as some measures may be better at detecting functional changes due to a particular therapeutic target. Instead of choosing between BBB, kinematics, and EMG in hopes of choosing the best one, it is possible to include all measurements to gain better resolution of the underlying syndrome. One benefit of a syndromics approach is that it incorporates information from all measures and circumvents arbitrary decisions about which outcomes reflect the "best measures" for therapeutic testing (see section "Statistical Pattern Detection: Coherent Patterns from Numerous Measurements"). 
Multiple Measurement Techniques for the Same Feature

The problem of determining the best measures is not limited to the relatively abstract concept of functional recovery. Even in the case of concrete concepts such as tissue sparing, there is little consensus on how to best quantify changes. There have been a variety of approaches taken for histopathological quantification $(38,90,259,264$, 276-284). In the older literature, histological analyses of SCI consisted of qualitative descriptions of "typical" cords from each experimental condition (259). In more recent studies, researchers have developed ways to quantify tissue loss; however, the methods for quantification are somewhat variable across studies. The general approach in SCI is to measure the amount of gray and/or white matter sparing at the site of injury (92). Some researchers have estimated the lesion epicenter by taking serial sections and identifying the section with the largest extent of lesion and then analyzing a single coronal section to represent the lesion extent (211). Using image analysis, the area of spared gray and white matter in this slice can be calculated and then compared across experimental groups. Others have estimated lesion volume by interpolating the volume between two slices from a fixed interval $(92,264)$. For example, Bresnahan et al. (1987) measured the area of five sections between the rostral and caudal ends of the lesion site. The volume between these sections was calculated as the frustum of a cone, with the two sections representing the two bases of the cone. Others have quantified tissue volume in multiple ways. For example, von Euler et al. (1996) quantified tissue loss in three ways: (1) designing an ordinal scale to describe the extent of tissue loss, (2) by assuming that the lesion volume is approximately shaped like two cones with adjacent bases, and (3) by using image analysis software to reconstruct the lesion site section by section. Although one would expect the image analysis method to be the most accurate, the other two methods correlated quite highly with the section by section reconstruction ( $r=0.93$ and $r=0.96$ for the ordinal and conical estimates, respectively). These high correlations imply that, although there is variability across lesion quantification techniques, different techniques may largely explain the same variance in tissue loss. Therefore, researchers can, in many cases, use an easy but primitive estimate of tissue sparing (such as the conical method) to assess tissue loss after SCI.

Others have quantified tissue using unbiased stereology (285). Stereology involves estimating tissue length, volume, area, and cell or fiber counts from sub-sampled sections to accurately reconstruct entire regions of the nervous system. Tissue volume can be determined using the Cavalieri method $(277,286,287)$, which, when combined with systematic random sampling and optical or physical dissector methods $(288,291)$, can produce a fairly accurate representation of total cell and/or fiber counts within a volume of tissue $(286,288-290)$. This allows us to test specific hypotheses about trauma-induced alterations in specific population of cells, fiber sparing, and regeneration. These same techniques can be applied to estimate cell volume using the nucleator method, which uses radial points from the center of a pre-defined focal point (e.g., nucleolus within a cell), to the perimeter of the particle (e.g., membrane), to give an estimation of particle size (292). Additionally, myelin thickness can be determined by direct orthogonal measurements in uniform, random locations (293). These methods of stereological tissue analysis have proven very useful for SCI researchers to show cutting-edge work regarding immune response $(9,294)$, neuronal survival (295, 296), and plasticity $(16,297)$. However, given the number of alternative quantification approaches, it remains unclear which histological approaches are best for predicting functional performance, and there is a need for integrative comparisons of these various measurement methods.

\section{Statistical Pattern Detection: Coherent Patterns from Numerous Measurements}

Determining the best way to integrate information from multiple measurements represents a major challenge for translational testing. The goal of basic research is to develop outcomes that are, at once, sensitive to mechanistic therapeutics and translatable to human disease features (298). Application of the appropriate statistical tools is critical for data integration. A variety of statistical tools have been used to analyze neurotrauma data. Statistical approaches can be generally divided into univariate approaches and multivariate approaches (Fig. 2). Univariate

\section{UNIVARIATE vS. MULTIVARIATE RELATIONSHIPS}

\section{Univariate:}

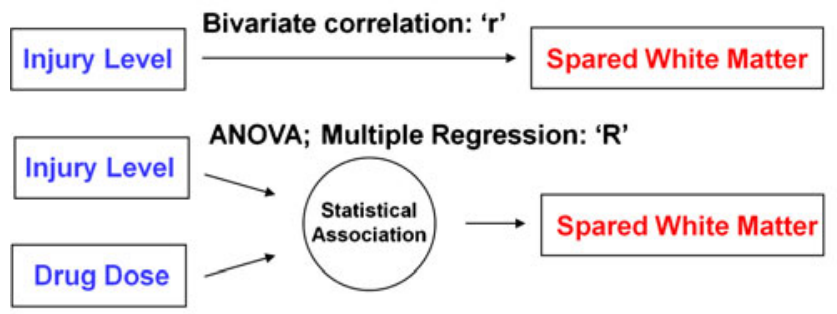

\section{Multivariate:}

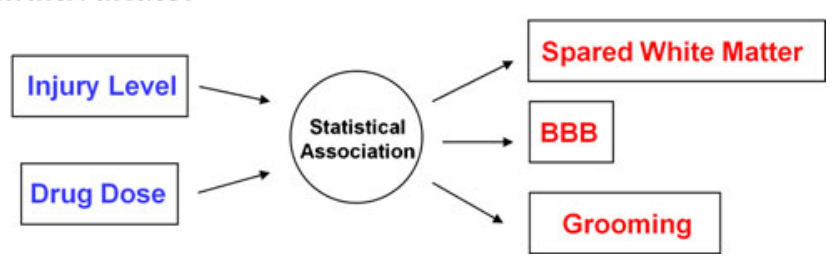

Fig. 2 Categories of statistical methods 
approaches focus on how a single variable changes as a function of either: (1) a therapeutic treatment, or (2) as a correlate of one or more predictor variables. Multivariate approaches, on the other hand, monitor changes in multiple variables at once, simultaneously measuring both individual outcomes as well as the inter-relationship among the outcomes. In this way, multivariate approaches are uniquely sensitive to therapeutic approaches that simultaneously affect multiple outcomes.

As highlighted in the preceding sections, neurotrauma research often involves multiple outcomes. The historical approach for dealing with this complexity has been to use univariate statistics to assess bivariate correlations among individual outcomes or to separately test a single hypothesis on multiple individual variables and report significance when it occurs (Fig. 3). Examples of common univariate methodologies include $t$ tests and analysis of variance, and bivariate correlational analysis wherein a single measure is correlated with another measure, and then this process is repeated iteratively for all outcomes $(6,151,299)$. Univariate approaches have been used in validation for many of the functional assessment techniques discussed above. The "gold standard" for validity testing has been to show that a functional measure correlates with tissue loss and/or intensity of experimental trauma. As a consequence, by design many of the functional measures do infer underlying tissue loss with reasonable reliability $(6,151$, 263, 299-301).

However, because there is some variability in the way that tissue loss is quantified (see section "Multiple Measurements for the Same Feature"), the validation procedures across different scales may not be comparable.
For example, the BBB scale was validated by testing whether the scale could predict the degree of experimental trauma (i.e., the degree of cord displacement or weight drop height). In addition, the scores were regressed onto the percentage of tissue sparing at the lesion epicenter (211). Other validation procedures that have used multiple quantification methodologies have found that histological quantification methods can influence conclusions about the validity of a scale $(92,264)$. Bresnahan et al. (1987) found that lesion area at the epicenter correlated better with three common functional measures (open-field locomotion, the inclined plane, and gridwalk) than lesion volume estimation (92). In contrast, von Euler et al. (1996) found that area of tissue loss at the lesion epicenter correlated less well with several functional measures than an ordinal lesion volume score (264). These findings illustrate the potential danger of drawing conclusions about the validity of a functional measure based on a unitary tissue quantification method. However, many functional measures do appear to reflect tissue changes in one form or another, suggesting that there is an underlying multi-dimensional disease state that is reflected across different quantification methods. Yet, univariate analyses are blind to consistent patterns among several outcomes $(16,302)$.

Multivariate statistical approaches represent a powerful alternative to univariate testing of neurotrauma data. Because multivariate approaches are sensitive to associations among multiple outcomes, they have the potential to identify underlying disease states that are unconstrained by the limitations of individual measures. This feature allows researchers to partition out the error that is particular to each outcome measure and to focus on the consistent disease

\section{UNIVARATE vS. MULTIVARIATE PROCESSING OF SCI DATA}

a

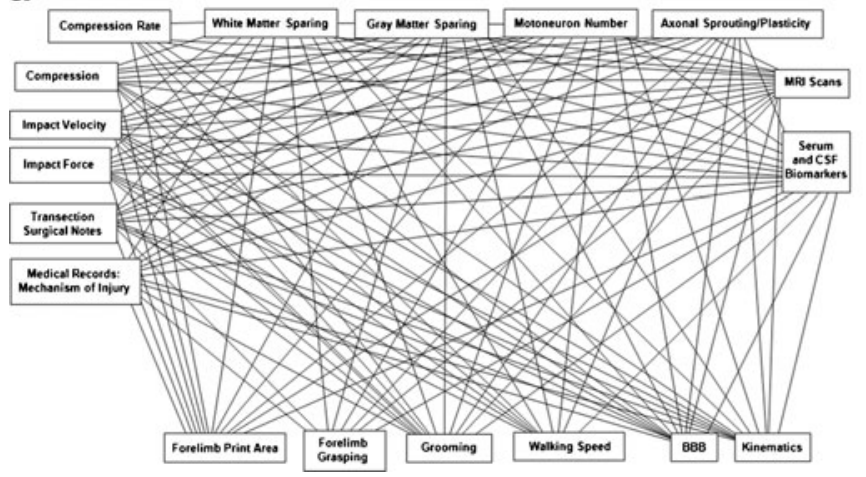

Fig. 3 Correlation distillation as a syndromic framework. The goal of syndromic analysis is to convert a low-level univariate statistical relationships (lines) among observed variables (boxes) into b a multivariate view of the underlying syndromic states (circles). The multivariate representation in $\mathbf{b}$, known as a path diagram, is consistent with the conventions of structural equation modeling where directional arrows are used to indicate cause-and-effect relationships. b

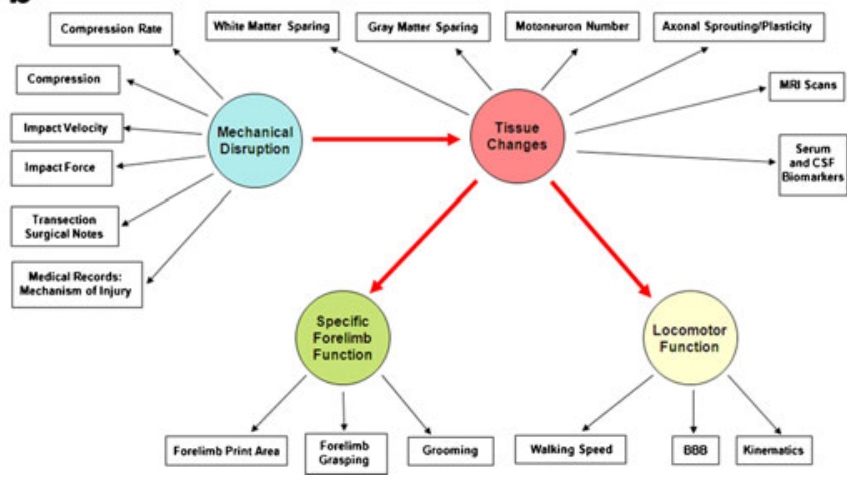

From this perspective, underlying syndrome states are conceptualized as the cause of observed outcomes, and multivariate outcome monitoring provides a more accurate window into the underlying syndrome. With more measures, the picture of the underlying syndrome becomes more clear and less distorted by the error in individual measures 
patterns that are shared across outcomes (303). This produces a dramatic increase in statistical power and helps identify robust disease patterns that are less likely to be idiosyncratic to a specific outcome measure (304). At the same time, multivariate approaches can be used to identify different classes of outcomes, which can be particularly beneficial for diagnosis and treatment in clinical neurotrauma $(305,306)$.

To date, only a small number of papers have applied multivariate approaches to basic research in SCI $(9,16,274$, 302, 307-314) and TBI models (315-317). A typical approach has been to use multivariate pattern detectors such as principal component analysis (PCA) to distill numerous measurement variables down to a small number of multivariate patterns. PCA (318) and related approaches such as exploratory factor analysis (303) are classical tools for detecting the common variance that is shared by multiple observed variables. This represents a powerful approach to consolidate data in a hypothesis-free manner to discover the underlying associations among measures. This may be especially useful in disease models such as SCI and TBI wherein researchers often have only vague notions that several outcomes might be related. For example, gray matter sparing, white matter sparing, and locomotor performance may move together as a group; however, there may not be strong hypotheses about the magnitude or multi-dimensional/ multi-inflected nature of that relationship $(92,241)$. It is conceivable that early functional performance could reflect gray matter sparing through early neuroprotection whereas later performance is predicted by an amalgamation of gray matter sparing as well as white matter sparing and remyelination $(49,69,319,320)$. Multivariate pattern detectors provide an unbiased way to identify these relationships in a manner that is untarnished by preconceptions (e.g., hypotheses) about how the data should look.

Once identified, multivariate patterns can be used as outcomes for statistical hypothesis testing. For example, Grau et al. (2004) used PCA to deal with multiple outcomes in a spinal contusion model (302). Numerous histological and behavioral variables were distilled using PCA to identify data-driven outcome clustering. In a second step, hypothesized group differences were tested using multivariate analysis of variance and linear discriminant function analysis. By testing for consensus between alternative approaches of data-driven and hypothesis-driven statistics, the authors were able to make strong arguments about multivariate patterns that were highly robust. Others, such as Courtine et al. (2009), used PCA to detect clustering of 135 kinematic variables into systematic patterns during recovery after spinal cord transection (307). These patterns were then used (in the form of PC scores) to test for therapeutic interventions, revealing therapeutics that affected a large number of outcomes as a coherent pattern. This can be thought of as a data-filtering approach that uses all of the information within the dataset as a preamble to hypothesis testing. In this way, the hypothesized therapeutic approach can be tested on the entire ensemble of outcomes through syndromic analysis.

In some neurotrauma datasets, however, the multivariate association among measures is an end in itself. For example, a recent paper was concerned with whether a novel morphological observation-extensive corticospinal tract sprouting in primates after $\mathrm{SCI}$-was related to functional performance (16). Fortunately, this group took multiple functional measures from the same animals (214, 226), enabling a syndromic analytical approach. Through rigorous measurement of multiple variables from EMG, kinematics, observational scales and tissue morphology, and matched efforts in data organization/data annotation, it was possible to perform syndromic analysis, revealing the multivariate association between the degree of CST sprouting and functional performance. This highlights the powerful opportunity for novel discoveries that can come from syndromic analysis, if neurotrauma researchers can develop well-organized multivariable datasets.

\section{Validation of Syndromic Patterns}

Once multivariate syndromic patterns are extracted, their validity and reliability can be assessed through a number of statistical and experimental approaches. For example, statistical perturbation analyses can be used to subsample subject populations (bootstrapping) or variable sets (feature selection) to evaluate the generality of syndromic patterns across diverse data types. An exhaustive review of such "model selection approaches" is beyond the scope of the present paper, and we refer readers to excellent outside sources (321). Multivariate approaches have been widely exploited to validate genomic patterns as predictors of a particular disease state (322). Preclinical neurotrauma research has powerful additional opportunity for syndromic validation beyond just statistical approaches. Trauma, unlike many other neurological diseases, has a known etiology that can be precisely replicated in the laboratory using controlled biomechanical injury devices (323-325). Syndromic patterns can be validated by their sensitivity to biomechanically defined injury gradations. This fundamental fact - that the basic etiology of neurotrauma is known - uniquely positions the neurotrauma literature to help tune translational syndromic methods for potential applications to other neurological diseases that do not benefit from a well-characterized etiology.

\section{Achieving High $\mathbf{N}$ through Data Sharing}

One of the hurdles for syndromic testing is that the typical sample size $(N)$ used in basic neurotrauma experiments is 
much smaller than traditionally thought to be required for multivariate statistical studies. Historically, multivariate statistical approaches, such as exploratory factor analysis and principal components analysis, were held to require sample sizes of $N>250$ for reliable detection of multivariate patterns (304). This traditional rule of thumb for sample size presents a challenge for syndromic analysis in neurotrauma models because it is a far greater $N$ than a typical basic research laboratory is able to achieve in a single study. However, recent Monte Carlo studies have suggested that multivariate methods can be reliably applied when certain statistical criteria are met (high communalities and high levels of component saturation) (326). These statistical features are often met in basic neurotrauma research because animal models are well-standardized, resulting in reduced error variance and better resolution at the multivariate level (327). In addition, the bioinformatics field has produced a number of new statistical methods, such as sparse principal components analysis, that are less vulnerable to distortions of multivariate patterns created by low $N$ s (328). Together, recent innovations in the statistical literature provide support for the application of multivariate approaches to 'low- $N$ ' basic neurotrauma research, as long as researchers apply the appropriate statistical safeguards (e.g., sparse PCA with the $L_{1}$ penalty (329)).

Although there are no technical difficulties with applying modern multivariate methods to small datasets, there is still a strong argument for developing large, shared datasets to improve translation of multivariate findings. By applying multivariate pattern detection on large-scale heterogeneous datasets, it becomes possible to identify emergent multivariate patterns that translate across diverse laboratories and models (175). The goal of taking such an approach is to identify consistent syndromic patterns that reflect translational measures of neurotrauma pathology (176) and therefore consistent targets for translational testing.

\section{Common Data Elements for Preclinical Animal Models}

Identification of candidate common data elements (CDEs) for basic animal research will be critical for the success of data-sharing efforts and syndromic analysis $(175,176)$. CDEs are variables that have well-defined operational definitions and use the same variable names across different studies. Under the direction of the National Institute of Neurological Diseases and Stroke (NINDS), the clinical neurotrauma literature has undertaken a substantial effort toward developing CDEs for clinical trials for both TBI (306, 330-334) and SCI (209). At the current time, the preclinical literature has lagged behind the clinical literature in identifying CDEs for translational testing, and there is a lack of consensus in the field as to the best methods to move forward $(28,29)$. Collaborative data-sharing across multiple laboratories has the potential to assist in this effort. With the exception of the MASCIS trial from the early 1990s (266), there are few examples of large-scale datasharing projects in the preclinical literature. We have recently undertaken a large-scale data-sharing effort involving several SCI research centers including UCSF, UCSD, UCLA, UCI, University of Louisville, and the Ohio State University $(175,176)$. The goal of this project is to develop a common database infrastructure for animal SCI research that will enable large-scale syndromic discovery and translation between species (Fig. 4).

\section{Syndromics as a Generalizable Framework for Multiple Diseases}

At the current time, most of the syndromic work for neurotrauma has been isolated to a small number of highprofile papers (16). However, we anticipate that syndromic approaches will begin to become prevalent in a wide variety of disease models. The goal is to monitor and capture as much information as possible about the state of the subject and then use advanced analytical techniques to leverage this information in the process of therapeutic testing. The syndromic approach represents a stark contrast from historical methods used in preclinical outcome research, which have relied heavily on pre-existing hypotheses and strong theoretical foundations. While hypothesis-driven research is a powerful approach for proof-of-concept testing in highly controlled experimental scenarios, it may not be the best method for detecting translational therapeutic effects in complex systems such as the injured nervous system in vivo (253-257).

\section{STEPS FOR SYNDROMIC ANALYSIS OF NEUROTRAUMA DATA}

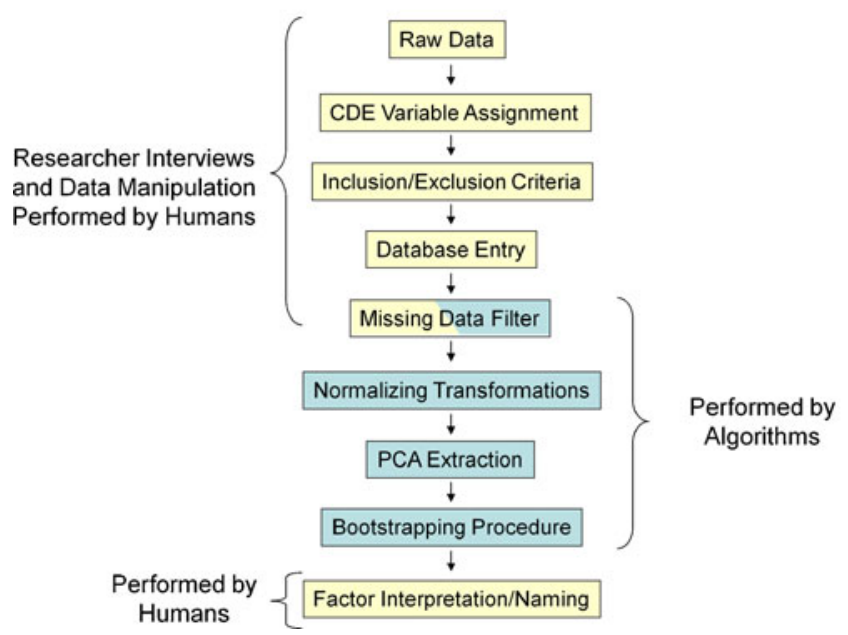

Fig. 4 Methodological workflow for syndromic analysis 
The clinical literature has long acknowledged the problem of complexity, and there would be substantial translational power gained by adopting similar analytic methods in the basic scientific research. Indeed, factor analysis, one of the first multivariate techniques, was developed to tackle the problem of complexity in human cognitive testing (303). These methods were later extended to a wide variety of clinical problems including human diagnostics such as intelligence tests $(303,335)$, neurocognitive inventories (336), electrocardiograms $(337,338)$, pain measures after SCI (339), and the AIS scale (340) and will greatly benefit our efforts in the preclinical models.

\section{Concluding Remarks}

In this review, we presented syndromics as a new framework for dealing with data from basic neurotrauma research. The goal of syndromics is to leverage existing knowledge within the vast basic science literature to discover new patterns within disease models. This approach is consistent with innovations in analytical methods for systematic reviews (341) and metaanalyses (342-344) in the sense that it combines findings from several sources to characterize the emergent trends within a field of study. However, unlike traditional metaanalyses of data that is extracted from published works, syndromic analysis involves access to the original raw data from diverse scales and relies heavily on open data-sharing among researchers (345). In recent years, the genomic field has pioneered data-sharing standards which have enabled new meta-analytic techniques such as gene-set enrichment analysis (GSEA) and on raw data in genomic databases or meta-GSEA which combines multi-center data after correcting for variance in gene expression across studies $(322,346-$ 348). However, at the current stage, there is little intrinsic incentive for preclinical neurotrauma researchers to engage in a similar data-sharing exercise using diverse histological and functional outcome sets for syndromic analysis. The NIH has a resource sharing policy that demands timely release and access to data upon request by other researchers for data collected as part of an NIH project (349). However, as previously pointed out (345), getting data to the point that it can be shared often requires substantial effort, and it is unclear who should shoulder this burden. It is understandable that researchers who have ongoing obligations to new projects will have little time/resources available to help index their old data, especially when data are collected by graduate students, postdocs, and other research staff who were not trained in standards for that file structures, variable names, and large-scale quantification methodologies.

Because multivariate techniques, such as those advocated in this review, are not yet common in the basic neurotrauma literature, the field has an opportunity to develop consensus- based standards for collection of multivariate basic neurotrauma data. In the immediate future, the field would benefit from the implementation of multivariate techniques to assess the redundancy of the current measures of function. This would streamline the current testing methods, allowing for a more organized literature. In the more distant future, the field could harness multivariate techniques to better assess the validity of new measures. In addition to methodological gains, researchers could use advanced statistical techniques such as structural equation modeling (e.g., Fig. 3b) to produce theoretical gains as well. Therefore, future work that leverages these methodologies is likely to be informative and applicable to multiple fields of study.

Acknowledgments The authors wish to thank Dr. Michael S. Beattie, Dr. Jacqueline C. Bresnahan, and Dr. J. Russell Huie for comments on an earlier version of this manuscript. This work was supported by National Institutes of Health (NIH) National Institute of Neurological Disorders and Stroke (NINDS) grants R01-NS069537 and R01-NS067092 to ARF.

Open Access This article is distributed under the terms of the Creative Commons Attribution Noncommercial License which permits any noncommercial use, distribution, and reproduction in any medium, provided the original author(s) and source are credited.

\section{References}

1. Singh IN, Sullivan PG, Deng Y, Mbye LH, Hall ED. Time course of post-traumatic mitochondrial oxidative damage and dysfunction in a mouse model of focal traumatic brain injury: implications for neuroprotective therapy. J Cereb Blood Flow Metab. 2006;26:1407.

2. Xiong Y, Rabchevsky AG, Hall ED. Role of peroxynitrite in secondary oxidative damage after spinal cord injury. J Neurochem. 2007;100:639.

3. Azbill RD, Mu X, Bruce-Keller AJ, Mattson MP, Springer JE. Impaired mitochondrial function, oxidative stress and altered antioxidant enzyme activities following traumatic spinal cord injury. Brain Res. 1997;765:283.

4. Crowe MJ, Bresnahan JC, Shuman SL, Masters JN, Beattie MS. Apoptosis and delayed degeneration after spinal cord injury in rats and monkeys. Nat Med. 1997;3:73.

5. Liu XZ et al. Neuronal and glial apoptosis after traumatic spinal cord injury. J Neurosci. 1997;17:5395.

6. Noble LJ, Wrathall JR. Correlative analyses of lesion development and functional status after graded spinal cord contusive injuries in the rat. Exp Neurol. 1989;103:34.

7. Maxwell WL, MacKinnon MA, Stewart JE, Graham DI. Stereology of cerebral cortex after traumatic brain injury matched to the Glasgow outcome score. Brain. 2010;133:139.

8. Schnell L, Fearn S, Klassen H, Schwab ME, Perry VH. Acute inflammatory responses to mechanical lesions in the CNS: differences between brain and spinal cord. Eur J Neurosci. 1999;11:3648.

9. Beck KD et al. Quantitative analysis of cellular inflammation after traumatic spinal cord injury: evidence for a multiphasic inflammatory response in the acute to chronic environment. Brain. 2010;133:433.

10. Jones TB, Hart RP, Popovich PG. Molecular control of physiological and pathological T-cell recruitment after mouse spinal cord injury. J Neurosci. 2005;25:6576. 
11. Kigerl KA, McGaughy VM, Popovich PG. Comparative analysis of lesion development and intraspinal inflammation in four strains of mice following spinal contusion injury. J Comp Neurol. 2006;494:578.

12. Jurkiewicz MT, Mikulis DJ, McIlroy WE, Fehlings MG, Verrier MC. Sensorimotor cortical plasticity during recovery following spinal cord injury: a longitudinal fMRI study. Neurorehabil Neural Repair. 2007;21:527.

13. Llewellyn-Smith IJ, Weaver LC. Changes in synaptic inputs to sympathetic preganglionic neurons after spinal cord injury. J Comp Neurol. 2001;435:226.

14. Resnick DK et al. Molecular evidence of repair and plasticity following spinal cord injury. Neuroreport. 2004;15:837.

15. Sydekum E et al. Functional reorganization in rat somatosensory cortex assessed by fMRI: elastic image registration based on structural landmarks in fMRI images and application to spinal cord injured rats. NeuroImage. 2009;44:1345.

16. Rosenzweig ES et al. Extensive spontaneous plasticity of corticospinal projections after primate spinal cord injury. Nat Neurosci. 2010;13:1505.

17. Cao Q et al. Functional and electrophysiological changes after graded traumatic spinal cord injury in adult rat. Exp Neurol. 2005;191 Suppl 1:S3.

18. David BT, Steward O. Deficits in bladder function following spinal cord injury vary depending on the level of the injury. Exp Neurol. 2010;226:128.

19. Filli L, Zorner B, Weinmann O, Schwab ME. Motor deficits and recovery in rats with unilateral spinal cord hemisection mimic the Brown-Sequard syndrome. Brain.

20. Fuller DD et al. Graded unilateral cervical spinal cord injury and respiratory motor recovery. Respir Physiol Neurobiol. 2009;165:245.

21. Guth L, Bright D, Donati EJ. Functional deficits and anatomical alterations after high cervical spinal hemisection in the rat. Exp Neurol. 1978;58:511.

22. Holbrook TL et al. Trauma in adolescents causes long-term marked deficits in quality of life: adolescent children do not recover preinjury quality of life or function up to two years postinjury compared to national norms. J Trauma. 2007;62:577.

23. Nedeltchev $\mathrm{K}$ et al. Long-term outcome of acute spinal cord ischemia syndrome. Stroke. 2004;35:560.

24. Allen AR. Surgery of experimental lesion of spinal cord equivalent to crush injury of fracture dislocation of spinal column. A preliminary report. J AM MED ASSOC. 1911;LVII:878.

25. Rivlin AS, Tator $\mathrm{CH}$. Objective clinical assessment of motor function after experimental spinal cord injury in the rat. $\mathrm{J}$ Neurosurg. 1977;47:577.

26. Blight AR, Tuszynski MH. Clinical trials in spinal cord injury. J Neurotrauma. 2006;23:586.

27. Kwon BK, Borisoff JF, Tetzlaff W. Molecular targets for therapeutic intervention after spinal cord injury. Mol Interv. 2002;2:244.

28. Kwon BK, Hillyer J, Tetzlaff W. Translational research in spinal cord injury: a survey of opinion from the SCI community. J Neurotrauma. 2010;27:21.

29. Kwon BK et al. A grading system to evaluate objectively the strength of pre-clinical data of acute neuroprotective therapies for clinical translation in spinal cord injury. J Neurotrauma 2010.

30. Kwon BK, Sekhon LH, Fehlings MG. Emerging repair, regeneration, and translational research advances for spinal cord injury. Spine (Phila Pa 1976). 2010;35:S263.

31. Chretien JP et al. Syndromic surveillance: adapting innovations to developing settings. PLoS Med. 2008;5:e72.

32. Di Giovanni $\mathrm{S}$ et al. Gene profiling in spinal cord injury shows role of cell cycle in neuronal death. Ann Neurol. 2003;53:454.

33. Carmel JB et al. Gene expression profiling of acute spinal cord injury reveals spreading inflammatory signals and neuron loss. Physiol Genomics. 2001;7:201.
34. Velardo MJ et al. Patterns of gene expression reveal a temporally orchestrated wound healing response in the injured spinal cord. J Neurosci. 2004;24:8562.

35. Song G, Cechvala C, Resnick DK, Dempsey RJ, Rao VL. GeneChip analysis after acute spinal cord injury in rat. J Neurochem. 2001;79:804.

36. Bartholdi D, Schwab ME. Expression of pro-inflammatory cytokine and chemokine mRNA upon experimental spinal cord injury in mouse: an in situ hybridization study. Eur J Neurosci. 1997;9:1422.

37. Yang L et al. Severity-dependent expression of pro-inflammatory cytokines in traumatic spinal cord injury in the rat. J Clin Neurosci. 2005;12:276.

38. Beattie MS, Farooqui AA, Bresnahan JC. Review of current evidence for apoptosis after spinal cord injury. J Neurotrauma. 2001;17:915.

39. Lu J, Ashwell KW, Waite P. Advances in secondary spinal cord injury: role of apoptosis. Spine (Phila Pa 1976). 2000;25:1859.

40. Wada $\mathrm{S}$ et al. Apoptosis following spinal cord injury in rats and preventative effect of $N$-methyl-D-aspartate receptor antagonist. J Neurosurg. 1999;91:98.

41. Ferguson AR et al. Cell death after spinal cord injury is exacerbated by rapid TNF alpha-induced trafficking of GluR2-lacking AMPARs to the plasma membrane. J Neurosci. 2008;28:11391.

42. Hall ED, Yonkers PA, Andrus PK, Cox JW, Anderson DK. Biochemistry and pharmacology of lipid antioxidants in acute brain and spinal cord injury. J Neurotrauma. 1992;9 Suppl 2:S425.

43. Hall ED, Braughler JM. Central nervous system trauma and stroke. II. Physiological and pharmacological evidence for involvement of oxygen radicals and lipid peroxidation. Free Radic Biol Med. 1989;6:303.

44. Braughler JM, Hall ED. Central nervous system trauma and stroke. I. Biochemical considerations for oxygen radical formation and lipid peroxidation. Free Radic Biol Med. 1989;6:289.

45. Choi DW, Weiss JH, Koh JY, Christine CW, Kurth MC. Glutamate neurotoxicity, calcium, and zinc. Ann N Y Acad Sci. 1989;568:219.

46. Choi DW. Glutamate neurotoxicity in cortical cell culture is calcium dependent. Neurosci Lett. 1985;58:293.

47. Agrawal SK, Nashmi R, Fehlings MG. Role of L- and $N$-type calcium channels in the pathophysiology of traumatic spinal cord white matter injury. Neuroscience. 2000;99:179.

48. Choi DW. Excitotoxic cell death. J Neurobiol. 1992;23:1261.

49. Park E, Velumian AA, Fehlings MG. The role of excitotoxicity in secondary mechanisms of spinal cord injury: a review with an emphasis on the implications for white matter degeneration. J Neurotrauma. 2004;21:754.

50. Grossman SD, Rosenberg LJ, Wrathall JR. Relationship of altered glutamate receptor subunit mRNA expression to acute cell loss after spinal cord contusion. Exp Neurol. 2001;168:283.

51. Carriedo SG, Sensi SL, Yin HZ, Weiss JH. AMPA exposures induce mitochondrial $\mathrm{Ca}(2+)$ overload and $\mathrm{ROS}$ generation in spinal motor neurons in vitro. J Neurosci. 2000;20:240.

52. Maciel EN, Vercesi AE, Castilho RF. Oxidative stress in $\mathrm{Ca}(2+)-$ induced membrane permeability transition in brain mitochondria. J Neurochem. 2001;79:1237.

53. Blight AR. Axonal physiology of chronic spinal cord injury in the cat: intracellular recording in vitro. Neuroscience. 1983;10:1471.

54. Nashmi R, Fehlings MG. Changes in axonal physiology and morphology after chronic compressive injury of the rat thoracic spinal cord. Neuroscience. 2001;104:235.

55. Nashmi R, Fehlings MG. Mechanisms of axonal dysfunction after spinal cord injury: with an emphasis on the role of voltage-gated potassium channels. Brain Res Brain Res Rev. 2001;38:165.

56. Wyllie AH. Glucocorticoid-induced thymocyte apoptosis is associated with endogenous endonuclease activation. Nature. 1980;284:555. 
57. Springer JE, Azbill RD, Knapp PE. Activation of the caspase-3 apoptotic cascade in traumatic spinal cord injury. Nat Med. 1999;5:943.

58. Li $\mathrm{M}$ et al. Functional role and therapeutic implications of neuronal caspase- 1 and -3 in a mouse model of traumatic spinal cord injury. Neuroscience. 2000;99:333.

59. Anderson KJ, Fugaccia I, Scheff SW. Fluoro-jade B stains quiescent and reactive astrocytes in the rodent spinal cord. $J$ Neurotrauma. 2003;20:1223.

60. Clark RS et al. Caspase-3 mediated neuronal death after traumatic brain injury in rats. J Neurochem. 2000;74:740.

61. Gavrieli Y, Sherman Y, Ben-Sasson SA. Identification of programmed cell death in situ via specific labeling of nuclear DNA fragmentation. J Cell Biol. 1992;119:493.

62. Schmued LC, Albertson C, Slikker Jr W. Fluoro-jade: a novel fluorochrome for the sensitive and reliable histochemical localization of neuronal degeneration. Brain Res. 1997;751:37.

63. Chan CC. Inflammation: beneficial or detrimental after spinal cord injury? Recent Pat CNS Drug Discov. 2008;3:189.

64. Popovich PG, Jones TB. Manipulating neuroinflammatory reactions in the injured spinal cord: back to basics. Trends Pharmacol Sci. 2003;24:13.

65. Bethea JR. Spinal cord injury-induced inflammation: a dualedged sword. Prog Brain Res. 2000;128:33.

66. Popovich PG, Wei P, Stokes BT. Cellular inflammatory response after spinal cord injury in Sprague-Dawley and Lewis rats. J Comp Neurol. 1997;377:443.

67. Bethea JR et al. Traumatic spinal cord injury induces nuclear factor-kappaB activation. J Neurosci. 1998;18:3251.

68. Bethea JR, Dietrich WD. Targeting the host inflammatory response in traumatic spinal cord injury. Curr Opin Neurol. 2002; 15:355.

69. Beattie MS. Inflammation and apoptosis: linked therapeutic targets in spinal cord injury. Trends Mol Med. 2004;10:580.

70. Blight AR. Delayed demyelination and macrophage invasion: a candidate for secondary cell damage in spinal cord injury. Cent Nerv Syst Trauma. 1985;2:299.

71. Dusart I, Schwab ME. Secondary cell death and the inflammatory reaction after dorsal hemisection of the rat spinal cord. Eur J Neurosci. 1994;6:712.

72. Brewer KL, Bethea JR, Yezierski RP. Neuroprotective effects of interleukin-10 following excitotoxic spinal cord injury. Exp Neurol. 1999;159:484.

73. Hermann GE, Rogers RC, Bresnahan JC, Beattie MS. Tumor necrosis factor-alpha induces cFOS and strongly potentiates glutamate-mediated cell death in the rat spinal cord. Neurobiol Dis. 2001;8:590.

74. Blight AR. Macrophages and inflammatory damage in spinal cord injury. J Neurotrauma. 1992;9 Suppl 1:S83.

75. Donnelly DJ, Popovich PG. Inflammation and its role in neuroprotection, axonal regeneration and functional recovery after spinal cord injury. Exp Neurol. 2008;209:378.

76. Jones TB, McDaniel EE, Popovich PG. Inflammatory-mediated injury and repair in the traumatically injured spinal cord. Curr Pharm Des. 2005;11:1223.

77. Hauben E, Schwartz M. Therapeutic vaccination for spinal cord injury: helping the body to cure itself. Trends Pharmacol Sci. 2003;24:7.

78. Ziv Y, Avidan H, Pluchino S, Martino G, Schwartz M. Synergy between immune cells and adult neural stem/progenitor cells promotes functional recovery from spinal cord injury. Proc Natl Acad Sci U S A. 2006;103:13174.

79. Pouw MH et al. Biomarkers in spinal cord injury. Spinal Cord. 2009;47:519.

80. Wienecke J, Westerdahl AC, Hultborn H, Kiehn O, Ryge J. Global gene expression analysis of rodent motor neurons following spinal cord injury associates molecular mechanisms with development of postinjury spasticity. J Neurophysiol. 2010;103:761.

81. Timofeev I et al. Cerebral extracellular chemistry and outcome following traumatic brain injury: a microdialysis study of 223 patients. Brain. 2011;134:484.

82. Mondello S et al. Neuronal and glial markers are differently associated with computed tomography findings and outcome in patients with severe traumatic brain injury: a case control study. Crit Care. 2011;15:R156.

83. Goodman JC, Robertson CS, Grossman RG, Narayan RK. Elevation of tumor necrosis factor in head injury. J Neuroimmunol. 1990;30:213.

84. Wang CX, Nuttin B, Heremans H, Dom R, Gybels J. Production of tumor necrosis factor in spinal cord following traumatic injury in rats. J Neuroimmunol. 1996;69:151.

85. Lee YB et al. Role of tumor necrosis factor-alpha in neuronal and glial apoptosis after spinal cord injury. Exp Neurol. 2000;166:190.

86. Nawashiro H, Tasaki K, Ruetzler CA, Hallenbeck JM. TNFalpha pretreatment induces protective effects against focal cerebral ischemia in mice. J Cereb Blood Flow Metab. 1997; 17:483.

87. Cheng B, Christakos S, Mattson MP. Tumor necrosis factors protect neurons against metabolic-excitotoxic insults and promote maintenance of calcium homeostasis. Neuron. 1994;12:139.

88. Turrin NP, Rivest S. Tumor necrosis factor alpha but not interleukin 1 beta mediates neuroprotection in response to acute nitric oxide excitotoxicity. J Neurosci. 2006;26:143.

89. Behrmann DL, Bresnahan JC, Beattie MS, Shah BR. Spinal cord injury produced by consistent mechanical displacement of the cord in rats: behavioral and histologic analysis. J Neurotrauma. 1992;9:197.

90. Noble LJ, Wrathall JR. Spinal cord contusion in the rat: morphometric analyses of alterations in the spinal cord. Exp Neurol. 1985;88:135.

91. Means ED, Anderson DK, Waters TR, Kalaf L. Effect of methylprednisolone in compression trauma to the feline spinal cord. J Neurosurg. 1981;55:200.

92. Bresnahan JC, Beattie MS, Todd 3rd FD, Noyes DH. A behavioral and anatomical analysis of spinal cord injury produced by a feedback-controlled impaction device. Exp Neurol. 1987;95:548.

93. Finkelstein SD, Gillespie JA, Markowitz RS, Johnson DD, Black P. Experimental spinal cord injury: qualitative and quantitative histopathologic evaluation. J Neurotrauma. 1990;7:29.

94. Ghirnikar RS, Lee YL, Eng LF. Chemokine antagonist infusion promotes axonal sparing after spinal cord contusion injury in rat. J Neurosci Res. 2001;64:582.

95. Faulkner JR et al. Reactive astrocytes protect tissue and preserve function after spinal cord injury. J Neurosci. 2004;24:2143.

96. Crang AJ, Gilson JM, Li WW, Blakemore WF. The remyelinating potential and in vitro differentiation of MOG-expressing oligodendrocyte precursors isolated from the adult rat CNS. Eur J Neurosci. 2004;20:1445.

97. Keirstead HS, Blakemore WF. The role of oligodendrocytes and oligodendrocyte progenitors in CNS remyelination. Adv Exp Med Biol. 1999;468:183.

98. Franklin RJ, Gilson JM, Blakemore WF. Local recruitment of remyelinating cells in the repair of demyelination in the central nervous system. J Neurosci Res. 1997;150:337.

99. Kotter MR, Li WW, Zhao CJ, Franklin RJ. Myelin impairs CNS remyelination by inhibiting oligodendrocyte precursor cell differentiation. J Neurosci. 2006;26:328.

100. McTigue DM, Horner PJ, Stokes BT, Gage FH. Neurotrophin-3 and brain-derived neurotrophic factor induce oligodendrocyte 
proliferation and myelination of regenerating axons in the contused adult rat spinal cord. J Neurosci. 1998;18:5354.

101. Sun F et al. Effects of axon degeneration on oligodendrocyte lineage cells: dorsal rhizotomy evokes a repair response while axon degeneration rostral to spinal contusion induces both repair and apoptosis. Glia. 2010;58:1304.

102. Wood PM, Bunge RP. The origin of remyelinating cells in the adult central nervous system: the role of the mature oligodendrocyte. Glia. 1991;4:225.

103. Okada S et al. Conditional ablation of Stat 3 or Socs 3 discloses a dual role for reactive astrocytes after spinal cord injury. Nat Med. 2006; 12:829

104. Herrmann JE et al. STAT3 is a critical regulator of astrogliosis and scar formation after spinal cord injury. $\mathrm{J}$ Neurosci. 2008;28:7231.

105. $\mathrm{Li} \mathrm{ZW}$, et al. Inhibiting epidermal growth factor receptor attenuates reactive astrogliosis and improves functional outcome after spinal cord injury in rats. Neurochem Int 2011 (in press).

106. Popovich PG, Streit WJ, Stokes BT. Differential expression of MHC class II antigen in the contused rat spinal cord. J Neurotrauma. 1993;10:37.

107. Rolls A et al. Two faces of chondroitin sulfate proteoglycan in spinal cord repair: a role in microglia/macrophage activation. PLoS Med. 2008;15:e171.

108. Shechter $\mathrm{R}$ et al. Infiltrating blood-derived macrophages are vital cells playing an anti-inflammatory role in recovery from spinal cord injury in mice. PLoS Med. 2009;6:e1000113.

109. Popovich PG et al. The neuropathological and behavioral consequences of intraspinal microglial/macrophage activation. J Neuropathol Exp Neurol. 2002;61:623.

110. Bareyre FM et al. The injured spinal cord spontaneously forms a new intraspinal circuit in adult rats. Nat Neurosci. 2004;7:269.

111. Galea MP, Darian-Smith. Corticospinal projection patterns following unilateral section of the cervical spinal cord in the newborn and juvenile macaque monkey. J Comp Neurol. 1997;381:282.

112. Kuang RZ, Kalil K. Specificity of corticospinal axon arbors sprouting into denervated contralateral spinal cord. J Comp Neurol. 1990;302:461.

113. Steward $\mathrm{O}$ et al. Regenerative growth of corticospinal tract axons via the ventral column after spinal cord injury in mice. J Neurosci. 2008;28:6836.

114. Weidner N, Ner A, Salimi N, Tuszynski MH. Spontaneous corticospinal axonal plasticity and functional recovery after adult central nervous system injury. Proc Natl Acad Sci U S A. 2001;98:3513.

115. Raineteau O, Fouad K, Bareyre FM, Schwab ME. Reorganization of descending motor tracts in the rat spinal cord. Eur $\mathrm{J}$ Neurosci. 2002;16:1761.

116. Fernandes KJ, Fan DP, Tsui BJ, Cassar SL, Tetzlaff W. Influence of the axotomy to cell body distance in rat rubrospinal and spinal motoneurons: differential regulation of GAP-43, tubulins, and neurofilament-M. J Comp Neurol. 1999;414:495.

117. Petruska JC et al. Changes in motoneuron properties and synaptic inputs related to step training after spinal cord transection in rats. J Neurosci. 2007;27:4460.

118. Khristy $\mathrm{W}$ et al. Changes in $\operatorname{GABA}(\mathrm{A})$ receptor subunit gamma 2 in extensor and flexor motoneurons and astrocytes after spinal cord transection and motor training. Brain Res. 2009;1273:9.

119. Hayashi M, Ueyama T, Nemoto K, Tamaki T, Senba E. Sequential mRNA expression for immediate early genes, cytokines, and neurotrophins in spinal cord injury. J Neurotrauma. 2000;17:203.

120. Nakamura M, Bregman BS. Differences in neurotrophic factor gene expression profiles between neonate and adult rat spinal cord after injury. Exp Neurol. 2001;169:407.
121. Widenfalk J, Lundstromer K, Jubran M, Brene S, Olson L. Neurotrophic factors and receptors in the immature and adult spinal cord after mechanical injury or kainic acid. J Neurosci. 2001;21:3457.

122. Menet V, Prieto M, Privat A, Gimenez y Ribotta M. Axonal plasticity and functional recovery after spinal cord injury in mice deficient in both glial fibrillary acidic protein and vimentin genes. Proc Natl Acad Sci U S A. 2003;100:8999.

123. Klapka $\mathrm{N}$ et al. Suppression of fibrous scarring in spinal cord injury of rat promotes long-distance regeneration of corticospinal tract axons, rescue of primary motoneurons in somatosensory cortex and significant functional recovery. Eur $\mathrm{J}$ Neurosci. 2005;22:3047.

124. Courtine $\mathrm{G}$ et al. Recovery of supraspinal control of stepping via indirect propriospinal relay connections after spinal cord injury. Nat Med. 2008;14:69.

125. Lavrov I et al. Plasticity of spinal cord reflexes after a complete transection in adult rats: relationship to stepping ability. J Neurophysiol. 2006;96:1699.

126. Rossignol S et al. Locomotor capacities after complete and partial lesions of the spinal cord. Acta Neurobiol Exp (Wars). 1996;56:449.

127. Ferguson AR, Crown ED, Grau JW. Nociceptive plasticity inhibits adaptive learning in the spinal cord. Neuroscience. 2006;141:421.

128. Edgerton VR et al. Use-dependent plasticity in spinal stepping and standing. Adv Neurol. 1997;72:233.

129. Grau JW, Barstow DG, Joynes RL. Instrumental learning within the spinal cord: I. Behavioral properties. Behav Neurosci. 1998;112:1366.

130. Patterson MM, Cegavske CF, Thompson RF. Effects of a classical conditioning paradigm on hind-limb flexor nerve response in immobilized spinal cats. J Comp Physiol Psychol. 1973;84:88.

131. Liu GT et al. Instrumental learning within the rat spinal cord: localization of the essential neural circuit. Behav Neurosci. 2005;119:538.

132. Joynes RL, Illich PA, Grau JW. Evidence for spinal conditioning in intact rats. Neurobiol Learn Mem. 1997;67:64.

133. Grau JW, Salinas JA, Illich PA, Meagher MW. Associative learning and memory for an antinociceptive response in the spinalized rat. Behav Neurosci. 1990;104:489.

134. Beggs AL, Steinmetz JE, Patterson MM. Classical conditioning of a flexor nerve response in spinal cats: effects of tibial nerve CS and a differential conditioning paradigm. Behav Neurosci. 1985;99:496.

135. Durkovic RG. Classical conditioning, sensitization and habituation in the spinal cat. Physiol Behav. 1975;14:297.

136. Fitzgerald L, Thompson R. Classical conditioning of the hindlimb flexion reflex in the acute spinal cat. Psychonomic Sci. 1967;8:213.

137. Buerger AA, Fennessy A. Learning of leg position in chronic spinal rats. Nature. 1970;225:751.

138. Crown ED, Ferguson AR, Joynes RL, Grau JW. Instrumental learning within the spinal cord. II. Evidence for central mediation. Physiol Behav. 2002;77:259.

139. Crown ED, Ferguson AR, Joynes RL, Grau JW. Instrumental learning within the spinal cord: IV. Induction and retention of the behavioral deficit observed after noncontingent shock. Behav Neurosci. 2002;116:1032.

140. Bigbee AJ et al. Two chronic motor training paradigms differentially influence acute instrumental learning in spinally transected rats. Behav Brain Res. 2007;180:95.

141. Jindrich DL et al. Spinal learning in the adult mouse using the Horridge paradigm. J Neurosci Methods. 2009;182:250.

142. Leblond H, L'Esperance M, Orsal D, Rossignol S. Treadmill locomotion in the intact and spinal mouse. J Neurosci. 2003;23:11411. 
143. Lovely RG, Gregor RJ, Roy RR, Edgerton VR. Weight-bearing hindlimb stepping in treadmill-exercised adult spinal cats. Brain Res. 1990;514:206.

144. Lovely RG, Gregor RJ, Roy RR, Edgerton VR. Effects of training on the recovery of full-weight-bearing stepping in the adult spinal cat. Exp Neurol. 1986;92:421.

145. Harkema SJ et al. Human lumbosacral spinal cord interprets loading during stepping. J Neurophysiol. 1997;77:797.

146. de Leon RD, Hodgson JA, Roy RR, Edgerton VR. Locomotor capacity attributable to step training versus spontaneous recovery after spinalization in adult cats. J Neurophysiol. 1998;79:1329.

147. Grau JW et al. Instrumental learning within the spinal cord: underlying mechanisms and implications for recovery after injury. Behav Cogn Neurosci Rev. 2006;5:191.

148. Joynes RL, Janjua K, Grau JW. Instrumental learning within the spinal cord: VI. The NMDA receptor antagonist, AP5, disrupts the acquisition and maintenance of an acquired flexion response. Behav Brain Res. 2004;154:431.

149. Blanco JE, Anderson KD, Steward O. Recovery of forepaw gripping ability and reorganization of cortical motor control following cervical spinal cord injuries in mice. Exp Neurol. 2007;203:333.

150. Endo T, Spenger C, Tominaga T, Brene S, Olson L. Cortical sensory map rearrangement after spinal cord injury: fMRI responses linked to Nogo signalling. Brain. 2007;130:2951.

151. Freund $\mathrm{P}$ et al. Disability, atrophy and cortical reorganization following spinal cord injury. Brain. 2011;134:1610.

152. Ghosh A et al. Functional and anatomical reorganization of the sensory-motor cortex after incomplete spinal cord injury in adult rats. J Neurosci. 2009;29:12210.

153. Henderson LA, Gustin SM, Macey PM, Wrigley PJ, Siddall PJ. Functional reorganization of the brain in humans following spinal cord injury: evidence for underlying changes in cortical anatomy. J Neurosci. 2011;31:2630.

154. Kaas JH et al. Cortical and subcortical plasticity in the brains of humans, primates, and rats after damage to sensory afferents in the dorsal columns of the spinal cord. Exp Neurol. 2008;209:407.

155. Kim BG, Dai HN, McAtee M, Vicini S, Bregman BS. Remodeling of synaptic structures in the motor cortex following spinal cord injury. Exp Neurol. 2006;198:401.

156. Schmidlin E, Wannier T, Bloch J, Rouiller EM. Progressive plastic changes in the hand representation of the primary motor cortex parallel incomplete recovery from a unilateral section of the corticospinal tract at cervical level in monkeys. Brain Res. 2004; 1017:172.

157. Martinez $M$ et al. Differential tactile and motor recovery and cortical map alteration after C4-C5 spinal hemisection. Exp Neurol. 2010;221:186.

158. Chervenak A, Foster I, Kesselman C, Salisbury C, Tuecke S. The data grid: towards an architecture for the distributed management and analysis of large scientific datasets. J Netw Comput Appl. 2000;23:187.

159. Desesquelles P. Multivariate analysis in nuclear physics. Ann Phys-Paris. 1995;20:1.

160. Kawano H, Higuchi T. The bootstrap method in space physics error estimation for the minimum variance analysis. Geophys Res Lett. 1995;22:307.

161. Monahan AH. Nonlinear principal component analysis by neural networks: theory and application to the Lorenz system. J Climate. 2000;13:821.

162. Coco G, Russo M. Using CATPCA to evaluate market regulation. In: Zani S, Cerioli A, Riani M, Vichi M, editors. Data analysis, classification and the forward search. Berlin: Springer; 2006.

163. Muthen B, Shedden K. Finite mixture modeling with mixture outcomes using the EM algorithm. Biometrics. 1999;55:463.
164. Northstone K, Emmett P, Team AS. Multivariate analysis of diet in children at four and seven years of age and associations with socio-demographic characteristics. Eur J Clin Nutr. 2005;59:751.

165. Panagiotakos D et al. Dietary patterns and 5-year incidence of cardiovascular disease: a multivariate analysis of the ATTICA study. Nutr Metab Cardiovasc Dis. 2009;19:253.

166. Linting M, Meulman JJ, Groenen PJF, van der Kooij AJ. Stability of nonlinear principal components analysis: an empirical study using the balanced bootstrap. Psychol Methods. 2007;12:359.

167. Kohonen $\mathrm{J}$ et al. Multi-block methods in multivariate process control. J Chemometr. 2008;22:580.

168. Chiang LH, Russell EL, Braatz RD. Fault diagnosis in chemical processes using fisher discriminant analysis, discriminant partial least squares, and principal component analysis. Chemometr Intell Lab. 2000;50:243.

169. Allen J et al. High-throughput classification of yeast mutants for functional genomics using metabolic footprinting. Nat Biotechnol. 2003;21:692.

170. Fiehn $\mathrm{O}$ et al. Metabolite profiling for plant functional genomics. Nat Biotechnol. 2000;18:1157.

171. Hiden HG, Willis MJ, Tham MT, Montague GA. Non-linear principle components analysis using genetic programming. Comput Chem Eng. 1999;23:413.

172. McQuisten KA, Peek AS. Comparing artificial neural networks, general linear models and support vector machines in building predictive models for small interfering RNAs. PLoS One. 2009;4:e7522.

173. Nicholson JK, Lindon JC, Holmes E. 'Metabonomics': understanding the metabolic responses of living systems to pathophysiological stimuli via multivariate statistical analysis of biological NMR spectroscopic data. Xenobiotica. 1999;29:1181.

174. Kleno TG et al. Mechanisms of hydrazine toxicity in rat liver investigated by proteomics and multivariate data analysis. Proteomics. 2004;4:868.

175. Nielson JL et al. Paper presented at the National Neurotrauma Symposium, Fort Lauderdale, FL, July 10-13, 2011.

176. Nielson JL et al. Paper presented at the Society for Neuroscience Annual Meeting, Washington, D.C., November 12-16, 2011.

177. Anderson K et al. Functional recovery measures for spinal cord injury: an evidence-based review for clinical practice and research. J Spinal Cord Med. 2008;31:133.

178. McDonald JW, Sadowsky C. Spinal-cord injury. Lancet. 2002;359:417.

179. DeVellis RF. Scale development: theory and applications. Applied social research methods series. 2nd ed. Thousand Oaks: Sage Publications, Inc; 2003. p. viii-171.

180. Carmines EG, Zeller RA. Reliability and validity assessment. A Sage University Paper: quantitative applications in the social sciences. Beverly Hills: Sage Publications; 1979. p. 70.

181. Cook DA, Beckman TJ. Current concepts in validity and reliability for psychometric instruments: theory and application. Am J Med. 2006;119:166 e7.

182. Messick S. In: Linn R, editor. Educational measurement. New York: American Council on Education and Macmillan; 1989.

183. Janda LH. Psychological testing:theory and applications. Needham Heights: Allyn \& Bacon; 1998.

184. Hanks RA et al. The predictive validity of a brief inpatient neuropsychologic battery for persons with traumatic brain injury. Arch Phys Med Rehabil. 2008;89:950.

185. Levin HS et al. Validity and sensitivity to change of the extended Glasgow Outcome Scale in mild to moderate traumatic brain injury. J Neurotrauma. 2001;18:575.

186. McCauley SR et al. The neurobehavioural rating scale-revised: sensitivity and validity in closed head injury assessment. J Neurol Neurosurg Psychiatry. 2001;71:643. 
187. Fann JR et al. Validity of the Patient Health Questionnaire-9 in assessing depression following traumatic brain injury. J Head Trauma Rehabil. 2005;20:501.

188. Thombs BD, Fauerbach JA, McCann UD. Stress disorders following traumatic injury: assessment and treatment considerations. Primary Psychiatry. 2005;12:51.

189. Forchheimer M, McAweeney M, Tate DG. Use of the SF-36 among persons with spinal cord injury. Am J Phys Med Rehabil. 2004;83:390.

190. Jang Y, Hsieh CL, Wang YH, Wu YH. A validity study of the WHOQOL-BREF assessment in persons with traumatic spinal cord injury. Arch Phys Med Rehabil. 2004;85:1890.

191. Lin MR, Hwang HF, Chen CY, Chiu WT. Comparisons of the brief form of the World Health Organization Quality of Life and Short Form-36 for persons with spinal cord injuries. Am J Phys Med Rehabil. 2007;86:104.

192. Roth E, Davidoff G, Haughton J, Ardner M. Functional assessment in spinal cord injury: a comparison of the Modified Barthel Index and the 'adapted' Functional Independence Measure. Clin Rehabil. 1990;4:277.

193. Davidoff GN, Roth EJ, Haughton JS, Ardner MS. Cognitive dysfunction in spinal cord injury patients: sensitivity of the Functional Independence Measure subscales vs neuropsychologic assessment. Arch Phys Med Rehabil. 1990;71:326.

194. Ditunno Jr JF et al. Walking index for spinal cord injury (WISCI): an international multicenter validity and reliability study. Spinal Cord. 2000;38:234.

195. Lawton $G$ et al. Cross-cultural validity of FIM in spinal cord injury. Spinal Cord. 2006;44:746.

196. Lam T, Noonan VK, Eng JJ. A systematic review of functional ambulation outcome measures in spinal cord injury. Spinal Cord. 2008;46:246

197. Ditunno Jr JF et al. Validity of the walking scale for spinal cord injury and other domains of function in a multicenter clinical trial. Neurorehabil Neural Repair. 2007;21:539.

198. Alexander MS et al. Outcome measures in spinal cord injury: recent assessments and recommendations for future directions. Spinal Cord. 2009;47:582.

199. Maynard Jr FM et al. International standards for neurological and functional classification of spinal cord injury. American Spinal Injury Association. Spinal Cord. 1997;35:266.

200. El Masry WS, Tsubo M, Katoh S, El Miligui YH, Khan A. Validation of the American Spinal Injury Association (ASIA) motor score and the National Acute Spinal Cord Injury Study (NASCIS) motor score. Spine (Phila Pa 1976). 1996;21:614.

201. Graves DE, Frankiewicz RG, Donovan WH. Construct validity and dimensional structure of the ASIA motor scale. J Spinal Cord Med. 2006;29:39.

202. Marino RJ, Graves DE. Metric properties of the ASIA motor score: subscales improve correlation with functional activities. Arch Phys Med Rehabil. 2004;85:1804.

203. Marino RJ, Shea JA, Stineman MG. The capabilities of upper extremity instrument: reliability and validity of a measure of functional limitation in tetraplegia. Arch Phys Med Rehabil. 1998;79:1512.

204. Anderson KD et al. United States (US) multi-center study to assess the validity and reliability of the Spinal Cord Independence Measure (SCIM III). Spinal Cord; 2011.

205. Kalsi-Ryan S et al. The Graded Redefined Assessment of Strength Sensibility and Prehension (GRASSP)-Reliability and validity. J Neurotrauma 2011 (in press).

206. Kalsi-Ryan S, Curt A, Fehlings MG, Verrier MC. Assessment of the hand in tetraplegia using the Graded Redefined Assessment of Strength, Sensibility and Prehension (GRASSP): impairment versus function. Top Spinal Cord Inj Rehabil. 2009;14:34.
207. DeVivo MJ, Biering-Sorensen F, New P, Chen Y. Standardization of data analysis and reporting of results from the International Spinal Cord Injury Core Data Set. Spinal Cord. 2011;49:596.

208. Biering-Sorensen $\mathrm{F}$ et al. Recommendations for translation and reliability testing of international spinal cord injury data sets. Spinal Cord. 2011;49:357.

209. Biering-Sorensen F et al. Incorporation of the International Spinal Cord Injury Data Set elements into the National Institute of Neurological Disorders and Stroke Common Data Elements. Spinal Cord. 2011;49:60.

210. Harkema SJ et al. Establishing the NeuroRecovery Network: multisite rehabilitation centers that provide activity-based therapies and assessments for neurologic disorders. Arch Phys Med Rehabil; 2011 (in press).

211. Basso DM, Beattie MS, Bresnahan JC. A sensitive and reliable locomotor rating scale for open field testing in rats. J Neurotrauma. 1995;12:1.

212. Basso DM et al. Basso Mouse Scale for locomotion detects differences in recovery after spinal cord injury in five common mouse strains. J Neurotrauma. 2006;23:635.

213. Irvine KA et al. A novel method for assessing proximal and distal forelimb function in the rat: the Irvine, Beatties and Bresnahan (IBB) forelimb scale. J Vis Exp. 2010;e2246. doi:10.3791/2246.

214. Nout YS et al. Methods for functional assessment after C7 spinal cord hemisection in the rhesus monkey. Neurorehabil Neural Repair; 2011 (in press).

215. Ferguson AR et al. A simple post hoc transformation that improves the metric properties of the BBB scale for rats with moderate to severe spinal cord injury. $J$ Neurotrauma. 2004;21:1601

216. Gale K, Kerasidis H, Wrathall JR. Spinal cord contusion in the rat: behavioral analysis of functional neurologic impairment. Exp Neurol. 1985;88:123.

217. Tarlov IM, Klinger H. Spinal cord compression studies. II. Time limits for recovery after acute compression in dogs. AMA Arch Neurol Psychiatry. 1954;71:271.

218. Hamers FP, Lankhorst AJ, van Laar TJ, Veldhuis WB, Gispen WH. Automated quantitative gait analysis during overground locomotion in the rat: its application to spinal cord contusion and transection injuries. J Neurotrauma. 2001;18:187.

219. Gensel JC et al. Behavioral and histological characterization of unilateral cervical spinal cord contusion injury in rats. J Neurotrauma. 2006;23:36.

220. Anderson KD, Gunawan A, Steward O. Quantitative assessment of forelimb motor function after cervical spinal cord injury in rats: relationship to the corticospinal tract. Exp Neurol. 2005;194:161.

221. Anderson KD, Gunawan A, Steward O. Spinal pathways involved in the control of forelimb motor function in rats. Exp Neurol. 2007;206:318.

222. Beare JE et al. Gait analysis in normal and spinal contused mice using the TreadScan system. J Neurotrauma. 2009;26:2045.

223. Brinkman J, Bush BM, Porter R. Deficient influence of peripheral stimuli on precentral neurones in monkeys with dorsal column lesions. J Physiol. 1978;276:27.

224. Courtine $G$ et al. Performance of locomotion and foot grasping following a unilateral thoracic corticospinal tract lesion in monkeys (Macaca muilatta). Brain. 2005;128:2338.

225. Ichiyama RM et al. Step training reinforces specific spinal locomotor circuitry in adult spinal rats. J Neurosci. 2008;28:7370.

226. Jindrich DL et al. Unconstrained three-dimensional reaching in Rhesus monkeys. Exp Brain Res. 2011;209:35.

227. Nashmi R, Imamura $\mathrm{H}$, Tator $\mathrm{CH}$, Fehlings MG. Serial recording of somatosensory and myoelectric motor evoked potentials: role 
in assessing functional recovery after graded spinal cord injury in the rat. J Neurotrauma. 1997;14:151.

228. Schallert T, Fleming SM, Leasure JL, Tillerson JL, Bland ST. CNS plasticity and assessment of forelimb sensorimotor outcome in unilateral rat models of stroke, cortical ablation, parkinsonism and spinal cord injury. Neuropharmacology. 2000;39:777.

229. Whishaw IQ, Pellis SM. The structure of skilled forelimb reaching in the rat: a proximally driven movement with a single distal rotatory component. Behav Brain Res. 1990;41:49.

230. Wong JK, Sharp K, Steward O. A straight alley version of the BBB locomotor scale. Exp Neurol. 2009;217:417.

231. Martinez M, Brezun JM, Bonnier L, Xerri C. A new rating scale for open-field evaluation of behavioral recovery after cervical spinal cord injury in rats. J Neurotrauma. 2009;26:1043.

232. Cheng $\mathrm{H}$ et al. Gait analysis of adult paraplegic rats after spinal cord repair. Exp Neurol. 1997;148:544.

233. Kunkel-Bagden E, Dai HN, Bregman BS. Recovery of function after spinal cord hemisection in newborn and adult rats: differential effects on reflex and locomotor function. Exp Neurol. 1992;116:40.

234. Metz GA, Dietz V, Schwab ME, van de Meent H. The effects of unilateral pyramidal tract section on hindlimb motor performance in the rat. Behav Brain Res. 1998;96:37.

235. Rossignol S, Drew T, Brustein E, Jiang W. Locomotor performance and adaptation after partial or complete spinal cord lesions in the cat. Prog Brain Res. 1999;123:349.

236. Smith RR et al. The Louisville Swim Scale: a novel assessment of hindlimb function following spinal cord injury in adult rats. $\mathrm{J}$ Neurotrauma. 2006;23:1654.

237. Basso DM. Behavioral testing after spinal cord injury: congruities, complexities, and controversies. J Neurotrauma. 2004;21:395

238. Kesslak JP, Keirstead HS. Assessment of behavior in animal models of spinal cord injury. J Spinal Cord Med. 2003;26:323.

239. Kunkel-Bagden E, Dai HN, Bregman BS. Methods to assess the development and recovery of locomotor function after spinal cord injury in rats. Exp Neurol. 1993;119:153.

240. Kwon BK, Oxland TR, Tetzlaff W. Animal models used in spinal cord regeneration research. Spine (Phila Pa 1976). 2002;27:1504.

241. Metz GA, Merkler D, Dietz V, Schwab ME, Fouad K. Efficient testing of motor function in spinal cord injured rats. Brain Res. 2000;883:165.

242. Muir GD, Webb AA. Mini-review: assessment of behavioural recovery following spinal cord injury in rats. Eur J Neurosci. 2000; $12: 3079$

243. Sedy J, Urdzikova L, Jendelova P, Sykova E. Methods for behavioral testing of spinal cord injured rats. Neurosci Biobehav Rev. 2008;32:550.

244. Thomas CK, Noga BR. Physiological methods to measure motor function in humans and animals with spinal cord injury. J RehabRes Dev. 2003;40:25.

245. Hamers FP, Koopmans V, Joosten EA. CatWalk-assisted gait analysis in the assessment of spinal cord injury. J Neurotrauma. 2006;23:537.

246. de Leon RD, Tamaki H, Hodgson JA, Roy RR, Edgerton VR. Hindlimb locomotor and postural training modulates glycinergic inhibition in the spinal cord of the adult spinal cat. J Neurophysiol. 1999;82:359.

247. Courtine $G$ et al. Kinematic and EMG determinants in quadrupedal locomotion of a non-human primate (Rhesus). J Neurophysiol. 2005;93:3127.

248. Magnuson DS et al. Swimming as a model of task-specific locomotor retraining after spinal cord injury in the rat. Neurorehabil Neural Repair. 2009;23:535.

249. Smith RR et al. Effects of swimming on functional recovery after incomplete spinal cord injury in rats. J Neurotrauma. 2006;23:908
250. Afelt Z, Blaszczyk J, Dobrzecka C. Stepping frequency and stride length in animal locomotion: a new method of investigation. Acta Neurobiol Exp (Wars). 1983;43:227.

251. Jeffery ND, Blakemore WF. Locomotor deficits induced by experimental spinal cord demyelination are abolished by spontaneous remyelination. Brain. 1997;120(Pt 1):27.

252. Webb AA, Muir GD. Course of motor recovery following ventrolateral spinal cord injury in the rat. Behav Brain Res. 2004;155:55.

253. Pinzon A et al. A re-assessment of erythropoietin as a neuroprotective agent following rat spinal cord compression or contusion injury. Exp Neurol. 2008;213:129.

254. Pinzon A et al. A re-assessment of minocycline as a neuroprotective agent in a rat spinal cord contusion model. Brain Res. 2008; $1243: 146$.

255. Sharp KG, Flanagan LA, Yee KM, Steward O. A re-assessment of a combinatorial treatment involving Schwann cell transplants and elevation of cyclic AMP on recovery of motor function following thoracic spinal cord injury in rats. Exp Neurol 2010 (in press).

256. Steward O et al. A re-assessment of the consequences of delayed transplantation of olfactory lamina propria following complete spinal cord transection in rats. Exp Neurol. 2006;198:483.

257. Steward O, Sharp K, Yee KM, Hofstadter M. A re-assessment of the effects of a Nogo-66 receptor antagonist on regenerative growth of axons and locomotor recovery after spinal cord injury in mice. Exp Neurol. 2008;209:446.

258. Valero-Cabre A, Fores J, Navarro X. Reorganization of reflex responses mediated by different afferent sensory fibers after spinal cord transection. J Neurophysiol. 2004;91:2838.

259. Tarlov IM. Spinal cord compression studies. III. Time limits for recovery after gradual compression in dogs. AMA Arch Neurol Psychiatry. 1954;71:588.

260. Grossman SD, Wolfe BB, Yasuda RP, Wrathall JR. Alterations in AMPA receptor subunit expression after experimental spinal cord contusion injury. J Neurosci. 1999;19:5711.

261. Grossman SD, Wrathall JR. The role of activity blockade on glutamate receptor subunit expression in the spinal cord. Brain Res. 2000;880:183.

262. Wrathall JR, Teng YD, Choiniere D. Amelioration of functional deficits from spinal cord trauma with systemically administered NBQX, an antagonist of non- $N$-methyl-D-aspartate receptors. Exp Neurol. 1996;137:119.

263. Wrathall JR, Choiniere D, Teng YD. Dose-dependent reduction of tissue loss and functional impairment after spinal cord trauma with the AMPA/kainate antagonist NBQX. J Neurosci. 1994;14:6598.

264. von Euler M, Akesson E, Samuelsson EB, Seiger A, Sundstrom E. Motor performance score: a new algorithm for accurate behavioral testing of spinal cord injury in rats. Exp Neurol. 1996;137:242.

265. Basso DM et al. MASCIS evaluation of open field locomotor scores: effects of experience and teamwork on reliability. Multicenter Animal Spinal Cord Injury Study. J Neurotrauma. 1996;13:343.

266. Young W. Spinal cord contusion models. Prog Brain Res. 2002;137:231.

267. Thomas Reuters. WebOfScience. In: Web of Knowledge; 2011.

268. Evans RM, Davies M. ScoreCentre: a computer program to assist with collection and calculation of BBB locomotor scale data. J Neurosci Methods. 2010;194:102.

269. Edgerton VR et al. Retraining the injured spinal cord. J Physiol. 2001;533:15.

270. Rossignol S. Locomotion and its recovery after spinal injury. Curr Opin Neurobiol. 2000;10:708.

271. Whelan PJ. Control of locomotion in the decerebrate cat. Prog Neurobiol. 1996;49:481. 
272. Courtine G, Schieppati M. Tuning of a basic coordination pattern constructs straight-ahead and curved walking in humans. J Neurophysiol. 2004;91:1524.

273. Koopmans GC et al. The assessment of locomotor function in spinal cord injured rats: the importance of objective analysis of coordination. J Neurotrauma. 2005;22:214.

274. Hillyer JE, Joynes RL. A new measure of hindlimb stepping ability in neonatally spinalized rats. Behav Brain Res. 2009;202:291

275. Nessler JA et al. Robotic gait analysis of bipedal treadmill stepping by spinal contused rats: characterization of intrinsic recovery and comparison with BBB. J Neurotrauma. 2006;23:882.

276. Wrathall JR, Pettegrew RK, Harvey F. Spinal cord contusion in the rat: production of graded, reproducible, injury groups. Exp Neurol. 1985;88:108.

277. Ditor DS et al. Magnetic resonance imaging versus histological assessment for estimation of lesion volume after experimental spinal cord injury. Laboratory investigation. J Neurosurg Spine. 2008;9:301.

278. Gonzalez-Lara LE et al. In vivo magnetic resonance imaging of spinal cord injury in the mouse. J Neurotrauma. 2009;26:753.

279. Lonjon $\mathrm{N}$ et al. Early functional outcomes and histological analysis after spinal cord compression injury in rats. J Neurosurg Spine. 2010;12:106.

280. Mihai $\mathrm{G}$ et al. Longitudinal comparison of two severities of unilateral cervical spinal cord injury using magnetic resonance imaging in rats. J Neurotrauma. 2008;25:1.

281. Nishi RA et al. Behavioral, histological, and ex vivo magnetic resonance imaging assessment of graded contusion spinal cord injury in mice. J Neurotrauma. 2007;24:674.

282. Olby NJ, Blakemore WF. A new method of quantifying the extent of tissue loss following spinal cord injury in the rat. Exp Neurol. 1996;138:82.

283. Qian J, Herrera JJ, Narayana PA. Neuronal and axonal degeneration in experimental spinal cord injury: in vivo proton magnetic resonance spectroscopy and histology. J Neurotrauma. 2010;27:599.

284. Scholtes F et al. Post-mortem assessment of rat spinal cord injury and white matter sparing using inversion recovery-supported proton density magnetic resonance imaging. Spinal Cord. 2011;49:345

285. Howard CV, Reed MG. Unbiased stereology: three dimensional measurement in microscopy. New York: Springer-Verlag; 1998.

286. Gundersen HJ, Jensen EB. The efficiency of systematic sampling in stereology and its prediction. J Microsc. 1987;147:229.

287. Howard CV, Reed MG. Unbiased stereology: three-dimensional measurement in microscopy. New York: Springer-Verlag; 1998. p. 39-54.

288. Gundersen HJ. Stereology of arbitrary particles. A review of unbiased number and size estimators and the presentation of some new ones, in memory of William R. Thompson. J Microsc. 1986;143:3.

289. West MJ. New stereological methods for counting neurons. Neurobiol Aging. 1993;14:275.

290. Gundersen HJ, Jensen EB, Kieu K, Nielsen J. The efficiency of systematic sampling in stereology-reconsidered. J Microsc. 1999;193:199.

291. Braendgaard H, Evans SM, Howard CV, Gundersen HJ. The total number of neurons in the human neocortex unbiasedly estimated using optical disectors. J Microsc. 1990;157:285.

292. Gundersen HJ. The nucleator. J Microscopy. 1988;151:3.

293. Larsen JO. Stereology of nerve cross sections. J Neurosci Methods. 1998;85:107.

294. Galvan MD et al. Deficiency in complement C1q improves histological and functional locomotor outcome after spinal cord injury. J Neurosci. 2008;28:13876.
295. Nielson JL et al. Unexpected survival of neurons of origin of the pyramidal tract after spinal cord injury. J Neurosci. 2010;30:11516.

296. Nielson JL, Strong MK, Steward O. A re-assessment of whether cortical motor neurons die following spinal cord injury. J Comp Neurol 2011 (in press).

297. Rosenzweig ES et al. Extensive spinal decussation and bilateral termination of cervical corticospinal projections in rhesus monkeys. J Comp Neurol. 2009;513:151.

298. Ellaway PH et al. Development of quantitative and sensitive assessments of physiological and functional outcome during recovery from spinal cord injury: a clinical initiative. Brain Res Bull. 2011;84:343.

299. Kuhn PL, Wrathall JR. A mouse model of graded contusive spinal cord injury. J Neurotrauma. 1998;15:125.

300. Teng YD et al. Functional recovery following traumatic spinal cord injury mediated by a unique polymer scaffold seeded with neural stem cells. Proc Natl Acad Sci U S A. 2002;99:3024.

301. Wang $X$ et al. Ibuprofen enhances recovery from spinal cord injury by limiting tissue loss and stimulating axonal growth. J Neurotrauma. 2009;26:81.

302. Grau JW et al. Uncontrollable stimulation undermines recovery after spinal cord injury. J Neurotrauma. 2004;21:1795.

303. Spearman C. "General intelligence" objectively determined and measured. Am J Psychol. 1904;15:201.

304. Stevens JP. Applied multivariate statistics for the social sciences. 5th ed. New York: Routledge; 2009.

305. McCauley SR et al. Recommendations for the Use of Common Outcome Measures in Pediatric Traumatic Brain Injury Research. J Neurotrauma 2011 (in press).

306. Saatman KE et al. Classification of traumatic brain injury for targeted therapies. J Neurotrauma. 2008;25:719.

307. Courtine $\mathrm{G}$ et al. Transformation of nonfunctional spinal circuits into functional states after the loss of brain input. Nat Neurosci. 2009; $12: 1333$.

308. Fong AJ et al. Spinal cord-transected mice learn to step in response to quipazine treatment and robotic training. J Neurosci. 2005;25:11738.

309. Hu Y et al. Somatosensory-evoked potentials as an indicator for the extent of ultrastructural damage of the spinal cord after chronic compressive injuries in a rat model. Clin Neurophysiol: Off J Int Fed Clin Neurophysiol. 2011;122:1440.

310. Jiang $\mathrm{H}$ et al. Establishing (1) $\mathrm{H}$ nuclear magnetic resonance based metabonomics fingerprinting profile for spinal cord injury: a pilot study. Chin Med J (Engl). 2010;123:2315.

311. Maier IC et al. Differential effects of anti-Nogo-A antibody treatment and treadmill training in rats with incomplete spinal cord injury. Brain. 2009;132:1426.

312. Negredo P, Rivero JL, Gonzalez B, Ramon-Cueto A, Manso R. Slow- and fast-twitch rat hind limb skeletal muscle phenotypes 8 months after spinal cord transection and olfactory ensheathing glia transplantation. J Physiol. 2008;586:2593.

313. Prasad A, Sahin M. Characterization of neural activity recorded from the descending tracts of the rat spinal cord. Front Neurosci. 2010;4:21.

314. Takeoka A et al. Axon regeneration can facilitate or suppress hindlimb function after olfactory ensheathing glia transplantation. J Neurosci. 2011;31:4298.

315. Pascual JM et al. Time course of early metabolic changes following diffuse traumatic brain injury in rats as detected by (1) H NMR spectroscopy. J Neurotrauma. 2007;24:944.

316. Vander Vorst M, Ono K, Chan P, Stuhmiller J. Correlates to traumatic brain injury in nonhuman primates. J Trauma. 2007;62:199.

317. Viant MR, Lyeth BG, Miller MG, Berman RF. An NMR metabolomic investigation of early metabolic disturbances following traumatic brain injury in a mammalian model. NMR Biomed. 2005;18:507. 
318. Pearson K. On lines and planes of closest fit to systems of points in space. Philos Mag. 1901;2:559.

319. Karimi-Abdolrezaee S, Eftekharpour E, Wang J, Morshead CM, Fehlings MG. Delayed transplantation of adult neural precursor cells promotes remyelination and functional neurological recovery after spinal cord injury. J Neurosci. 2006;26:3377.

320. Schwartz G, Fehlings MG. Evaluation of the neuroprotective effects of sodium channel blockers after spinal cord injury: improved behavioral and neuroanatomical recovery with riluzole. J Neurosurg. 2001;94:245.

321. Hastie T, Tibshirani R, Friedman JH. The elements of statistical learning: data mining, inference, and prediction. Springer series in statistics. 2nd ed. New York: Springer; 2009. p. xxii-745.

322. Subramanian A et al. Gene set enrichment analysis: a knowledge-based approach for interpreting genome-wide expression profiles. Proc Natl Acad Sci U S A. 2005;102:15545.

323. Gruner JA. A monitored contusion model of spinal cord injury in the rat. J Neurotrauma. 1992;9:123.

324. Scheff SW, Rabchevsky AG, Fugaccia I, Main JA, Lumpp Jr JE. Experimental modeling of spinal cord injury: characterization of a force-defined injury device. J Neurotrauma. 2003;20:179.

325. Dixon CE, Clifton GL, Lighthall JW, Yaghmai AA, Hayes RL. A controlled cortical impact model of traumatic brain injury in the rat. J Neurosci Methods. 1991;39:253.

326. Guadagnoli E, Velicer WF. Relation of sample size to the stability of component patterns. Psychol Bull. 1988;103:265.

327. Preacher KJ, MacCallum RC. Exploratory factor analysis in behavior genetics research: factor recovery with small sample sizes. Behav Genet. 2002;32:153.

328. Hastie T, Tibshirani R, Friedman J. The elements of statistical learning. New York: Springer; 2009. p. 1-101.

329. Zou H, Hastie T, Tibshirani R. Sparse principal component analysis. J Comput Graph Stat. 2006;15:265.

330. Thurmond VA et al. Advancing integrated research in psychological health and traumatic brain injury: common data elements. Arch Phys Med Rehabil. 2010;91:1633.

331. Whyte J, Vasterling J, Manley GT. Common data elements for research on traumatic brain injury and psychological health: current status and future development. Arch Phys Med Rehabil. 2010;91:1692.

332. Maas AI et al. Standardizing data collection in traumatic brain injury. J Neurotrauma. 2011;28:177.
333. Maas AI et al. Common data elements for traumatic brain injury: recommendations from the interagency working group on demographics and clinical assessment. Arch Phys Med Rehabil. 2010;91:1641

334. Manley GT et al. Common data elements for traumatic brain injury: recommendations from the biospecimens and biomarkers working group. Arch Phys Med Rehabil. 2010;91:1667.

335. McDonald RP. Test theory: a unified treatment. Mahwah: Lawrence Erlbaum Associates, Inc; 1999.

336. Gianutsos R, Glosser D, Elbaum J, Vroman GM. Visual imperception in brain-injured adults: multifaceted measures. Arch Phys Med Rehabil. 1983;64:456.

337. Rikli AE et al. Computer analysis of electrocardiographic measurements. Circulation. 1961;24:643.

338. Steinberg CA, Abraham S, Caceres CA. Pattern recognition in the clinical electrocardiogram. Trans IRE. 1962;9:23.

339. Widerstrom-Noga E. Chronic pain and nonpainful sensations after spinal cord injury: is there a relation? Clin J Pain. 2003;19:39.

340. Marino RJ et al. International standards for neurological classification of spinal cord injury. J Spinal Cord Med. 2003;26 Suppl 1:S50.

341. Mitchell CS, Lee RH. Pathology dynamics predict spinal cord injury therapeutic success. J Neurotrauma. 2008;25:1483.

342. Evans JA, Foster JG. Metaknowledge. Science. 2011;331:721.

343. Fehlings MG, Tator $\mathrm{CH}$. An evidence-based review of decompressive surgery in acute spinal cord injury: rationale, indications, and timing based on experimental and clinical studies. J Neurosurg. 1999;91:1.

344. Fernandez E et al. The adult "paraplegic" rat: treatment with cell graftings. Surg Neurol. 2006;65:223.

345. Gardner D et al. Towards effective and rewarding data sharing. Neuroinformatics. 2003;1:289.

346. Mootha VK et al. PGC-1alpha-responsive genes involved in oxidative phosphorylation are coordinately downregulated in human diabetes. Nat Genet. 2003;34:267.

347. Rhodes DR, Barrette TR, Rubin MA, Ghosh D, Chinnaiyan AM. Meta-analysis of microarrays: interstudy validation of gene expression profiles reveals pathway dysregulation in prostate cancer. Cancer Res. 2002;62:4427.

348. Zheng B et al. PGC-1alpha, a potential therapeutic target for early intervention in Parkinson's disease. Sci Transl Med. 2010;2:52ra73.

349. NIH, National Institute of Health: final NIH statement on sharing research data. Notice: NOT-OD-03-032, (2003). 